\title{
The Potential Renewable Energy for Sustainable Development in Tanzania: A Review
}

\author{
Obadia Kyetuza Bishoge ${ }^{1, *}$, Lingling Zhang ${ }^{1}$ and Witness Gerald Mushi ${ }^{2}$ \\ 1 School of Energy and Environmental Engineering, University of Science and Technology Beijing, \\ Beijing 100083, China; linglingzhangll@hotmail.com \\ 2 Anglican Church of Tanzania, Diocese of Masasi, Private Bag, Masasi, Tanzania; neatmushi2@gmail.com \\ * Correspondence: obishoge@yahoo.co.uk; Tel.: +86-13021251600
}

Received: 13 June 2018; Accepted: 22 July 2018; Published: 30 July 2018

\begin{abstract}
Currently, renewable energy development is emphasized for sustainable development goals accomplishment and the better realization of sustainable development globally. Tanzania, like other developing countries, is striving to adopt different ways of ensuring affordable and accessible energy supply to its socioeconomic and political sectors to achieve renewable energy development. To secure affordable and accessible energy in the country, renewable energy is termed as an alternative energy source because of it is environmentally friendly. If renewable energy is produced and utilized in a modern and sustainable manner, it will help to eliminate energy problems in Tanzania. Thus, this study aims to review the current potential renewable energy for the achievement of sustainable development in Tanzania. Moreover, challenges of renewable energy development are examined.
\end{abstract}

Keywords: clean energy; energy security; renewable energy resources; sustainable development; sustainable development goals

\section{Introduction}

Energy security is a socio-economic and political factor that contributes to sustainable development (SD) in any nation [1]. Access to reliable, affordable, sustainable, and modern energy to all people is one of the sustainable development goals (SDGs) [2]. Energy resources can be non-renewable or renewable; however, currently, the world is dominated by the usage of non-renewable energy such as fossil fuels. These are unsatisfactory because of their depletion and environmental concerns. For instance, currently, more than a half of the air pollution is contributed by energy globally. The use of non-renewable energy is considered the principal provider to climate change, which is about $60 \%$ of the total greenhouse gas emissions; therefore, decrease of carbon concentration is a key goal in long-term climate objectives [3-5]. Thus, the use of renewable energy is considered as alternative to the realization of sustainable development now and in the future. Furthermore, according to the Energy Watch Group, a global electricity system that relies on renewable energy is possible at every hour throughout the year and is most cost-effective compared to nuclear power and fossil fuels present [6].

Worldwide, the total primary energy demand rose about $2.0 \%$ in 2017 and is expected to rise around $30 \%$ in 2035 by increasing prosperity in terms of wealth generation and drivers for socio-economic development in developed and developing countries, partially offset by a fast improvement in energy efficacy [7]. More than $21 \%$ of the population globally lacks access to contemporary electricity by which 3,000 million people rely on traditional fuels such as firewood, coal, animal slurry, and charcoal for heating and cooking [8]. The use of solid fuels leads to illness, which causes the death of 4 million people in the world [8,9].

Energy glitches are currently serious in developing countries, especially in Africa where the electrification rate is very low [10]. Governments fail to offer adequate energy supply services to poor 
communities. Despite the fact that African countries are rich in renewable energy resources, only a low amount is harvested for domestic use [11]. In Sub-Saharan African (SSA) countries, only $25 \%$ of the population accesses electricity. According to the new research works, Africa's massive potential for renewable energy could supersede the continent's projected electricity demand in 2030 [12]. About $85 \%$ of primary energy supply in SSA nations is from traditional biomass energy, while less than $8 \%$ of the rural population has access to modern energy technologies $[13,14]$.

To ensure sufficient, efficient, environmentally friendly, and sustainable energy supply, the use of renewable energy resources is the best option for substituting non-renewable energy use. Globally, renewable energy resources entail hydropower, solar, wind, wave, geothermal power, waste energy such as gases from landfills, incineration, biomass, and liquid biofuels. Notwithstanding its significance, renewable energy still embodies only a low ratio of the current global energy production, supply, and consumption. Renewable power generation is over $23 \%$ (hydro $16 \%$ and non-hydro renewables $7.1 \%$ ) [15].

In Tanzania, major sources of power are natural gas, petroleum, and hydropower. Out of the total installed power capacity of 1,264 megawatts (MW), $568 \mathrm{MW}$ is from hydroelectric power, 685.4 MW is from thermal power, and other renewable energy contributes less than 82.4 MW [16]. More than $85 \%$ of the population uses traditional fuels as household energy sources [17]. According to Bureau of Statistics and the Rural Energy Agency report [18], only 32.8\% of communities in Tanzania has access to electricity, whereby urban areas have more access to electricity $(65.3 \%)$ than the rural areas $(16.9 \%)$. Out of the total electrified households, $74.9 \%$ and $24.7 \%$ are electrified with national grid and solar power, respectively. The rest $(0.3 \%)$ are electrified with individual electricity produced from other sources such as small generators.

Tanzania has a lot of renewable energy sources such as biomass, solar, hydropower, geothermal, biogas, wind, tidal, and waves [19]. These sources are important for decentralized renewable energy technologies, which nurture the isolated nature of the settlements and are environmental friendly [1]. Despite their necessity, renewable energy sources are given low priority by both government and households. They are important to users in local households in the countryside, where most people depend on the use of charcoal, firewood, and cow dung as their major sources of energy. This affects their health and contributes to climate change problems, which are alarming in developing countries.

This study, therefore, aims to review the current potential renewable energy for SD in Tanzania. Moreover, the challenges of renewable energy development are examined.

\section{SDGs}

$\mathrm{SD}$ is a development that considers the requirements of the current generation without compromising future generations [20-22]. In 2015, the world approved SDGs with a vision of poverty alleviation, planet protection, and safeguarding that all people enjoy peace and prosperity [23,24]. This vision is comprised of 17 goals and 169 targets. The SDGs include [25,26]:

1. Poverty alleviation in all areas.

2. Elimination of hunger by achieving food security and nutrition through the promotion of sustainable agriculture.

3. Good health promotion at all levels.

4. Insurance of comprehensive and justifiable quality education.

5. The accomplishment of gender equality by empowering girls and women to participate fully in the socioeconomic and political sectors.

6. Guaranteeing the availability of and access to water and environmental health services.

7. Safeguarding access to sustainable and modern energy.

8. Improvement of full, inclusive, and productive employment opportunities to all.

9. Building of strong infrastructure for the realization of sustainable innovation and industrialization. 
10. Elimination of inequalities within and among nations.

11. Ensuring safe and strong human settlements and cities.

12. Safeguarding sustainable production and consumption forms.

13. Elimination of climate change and its effects.

14. Sustainable conservation of water bodies resources.

15. Protection of biodiversity life by managing forests, combat land degradation, and desertification.

16. Promotion of peace, security, and justice at all levels.

17. Strengthening of the global partnership.

SDGs replaced Millennium Development Goals.

\section{Goal Number 7 on Accessible and Modern Energy}

As the global population rises, energy demand increases too. The current population depends on fossil fuels, which causes the drastic changes in the climate [26]. Efforts to inspire clean energy have arisen in more than $20 \%$ of the global power being produced by renewable energy resources as of 2014 . $14.3 \%$ of the population lacks access to electricity, and as the energy demand continues to increase there the production of renewable energy around the world will also need to increase.

Investment in spotless and renewable energy sources such as hydro, solar, biomass, wind, and thermal power is an approach towards achieving universal access to cheap and affordable electricity by 2030 [27]. To achieve this and reduce global electricity consumption in industries and homes by $14 \%$, there is the need for the adoption of cost-effective standards for a broad range of technologies. Each developing country is encouraged to expand its infrastructure and upgrade technologies to offer clean energy as a basic goal that can inspire socio-economic and political growth and environmental enhancement. Furthermore, renewable energy is expected to increase direct and indirect employment opportunities from 10.3 million in 2017 to 24 million in 2030 [28,29].

The goal consists of five targets that insist that by 2030, there should be the following [26]:

1. Equal access to affordable, reliable, and modern energy services.

2. An increased stake of renewable energy in the total global energy needs.

3. Doubled global population rate with improvement in energy efficiency.

4. Promotion of international cooperation to permit investment in renewable energy technologies and growth.

5. Expansion and upgrading of energy infrastructure and technologies and enhancement of the supply of contemporary and viable energy services to all communities in emerging nations.

This goal is also structured into three main areas, namely, renewable energy, energy efficiency, and energy access. This study is based on renewable energy in connection with energy access, efficiency, and security towards sustainable development in Tanzania.

\section{Tanzanian Context about SDGs}

Tanzania has made substantial changes in recent years in its development of the socioeconomic and political sectors' [30,31]. Poverty rate has been reduced and economic growth has increased with the progressive rise of infrastructure construction; improvement of public services such as education, health, and water supply; and increase of skilled labor force through diverse training programs $[32,33]$. Tanzania can rejoice, as it has attained some of the Millennium Development Goals, but at the same time there are a lot of challenges impeding national growth [34], and it was rated third unhappiest country out of 155 countries globally in 2017 [35]. A report recommended that the country lacks happiness as a consequence of its high level of poverty, shortage of investment in socioeconomic infrastructures such as energy and social services, poor governance, dissatisfaction with democracy, and negligence of satisfaction of the future generation needs. These concerns have caused considerable discussion about socioeconomic and political development change. 
There are key indicators in relation to sustainable development challenges in Tanzania. They are grouped into three categories, namely, social, economic, and environmental. Social concerns comprise high population growth, high burden of disease, poor social security coverage, gender inequality, low rate of health insurance, and expenses. Economic concerns involve high poverty level, public debt, and unemployment rate; low economic growth; and economic inequality among the people. Environmental concerns include an inadequate rate of energy access; high rate of land degradation and deforestation; inadequate supply of water services; and poor exploitation of natural resources such as minerals, coal, natural gas, and forests [36]. Thus, Tanzania has to make progressive prioritization and solemn resource mobilization from domestic and international sources to achieve full implementation of SDGs [37]. There is a need for more effort to improve the productive capacity of the poor, ensure quality service delivery, eliminate inequality, promote sustainable environmental management, and enhance good governance.

In Tanzania, SDGs relate to other programs such as Agenda 2063, which is a global strategy to optimize the utility of natural resources in Africa for the benefit of all to guarantee positive socioeconomic and political alteration and development within the next 50 years [38]. The Tanzania Development Vision 2025, which insists that Tanzania should be a country permeated with certain qualities, namely, good governance; high-quality livelihood; peaceful, unified, and stable society; a modest economy; and a knowledgeable society by 2025 [39].

The Tanzanian government is committed to fulfill SD Goal number 7 by providing affordable, reliable, sustainable, and modern energy for all Tanzanians by 2030 [40]. To achieve this goal, investments are required in the generation, transmission, and distribution of energy infrastructure. Tanzania plans to increase power generation predominantly by using more natural gas with coal and renewables such as hydropower, wind, solar, and thermal energies. To facilitate the required capital, the country has embarked on an ambitious programme of reforms aimed at increasing efficiency and service delivery and creating conditions for greater financial sustainability and private investments [41].

Electricity Supply Industry Reform Strategy and Roadmap 2014-2025 are among the programs that are entrusted to realize sustainable energy supply in the country. ESI aims at foreseeing power utility restructuring, progressive decentralization of energy generation, and transmission and distribution to different companies. This is expected to increase the efficiency and quality of goods and services; reduce subsidies with regard to energy supply; enhance transparency and competition among the investors in the energy sector; increase access to affordable power; and enrich satisfaction of business partners, their shareholders, and clients [41]. Moreover, there are Tanzania Renewable Energy Clean Development Programs that aim to improve energy development and environmental conservation toward expelling climate change in the nation [42].

Various forums, workshops, seminars, and training are conducted among stakeholders from parliament, government, civil society, and academia examining the determinants of change and policy adaptation on renewable energy in Tanzania and the challenges of reforming policy, and providing remarks for the execution and implementation of renewable energy policies and strategies [43].

\section{Potential Renewable Energy Sources in Tanzania}

\subsection{Hydropower}

Hydropower is the utmost widely-utilized renewable energy source in the world. It contributes about $1000 \mathrm{GW}$ [44], with over $16 \%$ of the global net electricity production [45] and with over $65 \%$ of the world's power generated from renewable energy resources [46]. Hydropower generation is constructed in water reserves. Globally, China has the biggest hydroelectric generation capacity in the world, followed by Brazil, the United States, Canada, and Russia.

Currently, hydropower constitutes over $45 \%$ of the total power generated in Tanzania. It has customarily played a notable role with an installed capacity of $561 \mathrm{MW}$, which is approximately one-third of total installed power capacity with expected 2612 MW [47], as indicated in Table 1. 
Tanzania has the potential hydropower of over $3.173 \mathrm{GW}$, as shown in Table 1, which enhances the country to plan for further development, but due to challenges such as weak transmission infrastructure, this sector is still in a poor state [48]. Recently, hydropower dominated the power industry of Tanzania, before being taken over by the natural gas. However, hydropower plants face the problem of unreliable rainfall. This is further aggravated by agricultural activities that take place in rivers upstream. This forces the government to find alternative measures such as natural gas to forge an energy mix, which may ensure efficient, reliable, and affordable power in the community.

Table 1. Hydropower plants in Tanzania as of June 2017 [47].

\begin{tabular}{clccc}
\hline No. & Power Station & Installed Capacity (MW) & System & Region \\
\hline 1. & Kidatu & 204 & Great Ruaha River & Morogoro \\
2. & Kihansi & 180 & Kihansi River & Morogoro \\
3. & Mtera & 80 & Great Ruaha River & Dodoma \\
4. & New Pangani Falls & 68 & River Pangani & Tanga \\
5. & Hale & 21 & River Pangani & Tanga \\
6. & Nyumba ya & 8 & River Pangani & Tanga \\
& Mungu & 561 & - & - \\
\hline & Sub Total & Expected & & \\
\hline 1. & Stiegler's Gorge & 2100 & Rufiji River & Morogoro \\
2. & Kikonge & 300 & Ruhuhu River & Ruvuma \\
3. & Songwe & 180 & Songwe River & Songwe \\
4. & Rumakali & 22 & Rumakali River & Iringa \\
5. & Small hydropower & $<10$ & Various rivers & Various regions \\
\hline & Sub Total & 2612 & - & - \\
& Grand Total & 3173 & - & - \\
\hline
\end{tabular}

There are small, mini, and micro hydro power plants, which are estimated to have installed capacity of $41.9522 \mathrm{MW}$ in Tanzania, as indicated in Table 2. Most of these plants are owned by either community or institutions. They are located in rural areas and aim to provide electricity to the community or institutions.

Table 2. Existing small, mini, and micro hydro plants $[49,50]$.

\begin{tabular}{clcc}
\hline No. & \multicolumn{1}{c}{ Power Station } & Installed Capacity (MW) & Location \\
\hline 1 & Ndola & 10 & Ruhuhu \\
2 & Kitonga & 10 & Ikololo \\
3 & Andoya Hydroelectric Power Ltd. & 1 & Mbinga \\
4 & ACRA Tanzania & 0.3 & Ludewa \\
5 & Mapembasi hydro Power Ltd & 12 & Njombe \\
6 & Mwenga Mini Hydro Ltd & 4 & Iringa \\
7 & Kikuletwa & 1.160 & Moshi \\
8 & Tosamaganga & 1.22 & Iringa \\
9 & Uwemba & 0.8 & Njombe \\
10 & Mbarali & 0.7 & Mbeya \\
11 & Bulongwa & 0.18 & Makete \\
12 & Ngaresero & 0.155 & Arusha \\
13 & Ngarenanyuki & 0.1 & Arusha \\
14 & Makumira & 0.1 & Arusha \\
15 & Mamba & 0.1 & Katavi \\
16 & Ikonda & 0.04 & Njombe \\
17 & Ndanda & 0.0144 & Masasi \\
18 & Nyangao & 0.0388 & Lindi \\
19 & Kaegesa & 0.044 & Sumbawanga \\
\hline
\end{tabular}


Different studies are taken into account to analyze the economic aspects and highlight various sites that could have potential for electricity generation at low cost to supply power to the national grid and through mini-grids to the villages in the community.

\section{Stiegler's Gorge Hydroelectric Power Station (SGHPS)}

SGHPS is a planned 2100 megawatts hydroelectric dam in Tanzania [51-53]. It is expected to produce $5920 \mathrm{GWh}$ of power annually [54]. The project has been presented as an energy generating option for Tanzania since the 1960's. It is considered a silver bullet to solve Tanzania's energy needs. It is now listed in the Tanzania Power System Master Plan (2016 update), to be built by 2035. Stiegler's Gorge is situated in the Selous Game Reserve, a World Heritage Site. Selous Game Reserve is a teamster for sustainable development by providing long-term benefits to Tanzania through tourism. World Wildlife Fund opposes development of the SGHPS in protected areas that negatively affect its ecological core values, especially those of World Heritage Sites (Exceptional Universal Value). In February 2017, The International Union for Conservation of Nature acknowledged the construction of Stiegler's Gorge would negatively impact the ecology of the Selous game reserves and life of organisms living outside the protected areas [55].

Despite the fact that the project will help to eliminate energy problems in Tanzania and thereby increase socio-economic and political growth, its implementation is expected to provide negative environmental impacts, as follows:

- The dam is expected to trap an estimated 16.6 million tonnes of sediment and nutrients annually [56]. This will lead to increased erosion downstream, soil fertility loss due to reduced flooding of farmlands, and the shrinking of the Rufiji delta and of the largest mangrove forest in East Africa.

- The project will affect ecosystem services, whereby about 200,000 people's livelihoods, such as farmers and fishermen in Rufiji delta and neighbor areas, will be at risk [53,57].

- It will risk the integrity of other globally noteworthy protected areas. The project will disturb the Rufiji-Mafia-Kilwa Marine Ramsar site through delta reduction and harm of marine species deposit and nutrients. Furthermore, the project will likely stop the seasonal migration of fish from the Rufiji River to the Kilombero Valley Floodplains Ramsar site upstream.

In general, Stiegler's gorge project is antagonistic to the current planned investment in the tourist industry in Selous game reserves [51]. However, it would be difficult for the country to avoid this project.

\subsection{Wind Energy}

Currently, there is a manifold upsurge of wind energy plants across the world. Wind is the second most applied renewable energy source in the world with the total installed capacity of $539.123 \mathrm{GW}$ in 2017 [58], an annual growth of 12.6\% [59]. China is the largest wind generator with an installed capacity of $188.392 \mathrm{GW}$ followed by the US (89.077 GW), Germany (56.132 GW), India (32.848 GW), and Spain (23.17 GW). African and Middle Eastern countries contribute to only $4.528 \mathrm{GW}$ of the total installed wind capacity. South Africa leads the African countries with an installed capacity of 2.085 GW [58].

Currently, in Tanzania, the expansion of community interest in wind electricity generation is prejudiced by factors such as an increase in oil costs, a long hydropower drought, and increased demand for power, which is influenced by high population growth. Tanzania has areas of high wind potential that cover more than $10 \%$ of its land [60]. This is equivalent in size to Malawi and has greater potential than the US state of California, as reported by the World Bank report. There are areas with annual average wind speeds of $5-8 \mathrm{~m} / \mathrm{s}$ [61]. These exist along a coastline of about $800 \mathrm{~km}$ with predominant surface winds, moving from south-east to northeast. Based on the current research works, Tanzania has a lot of wind energy resources in the areas of Great Lakes, the plains, 
and the highland plateau regions of the Rift Valley. Wind energy evaluation indicates that areas such as Makambako (Njombe) and Kititimo (Singida) have sufficient wind speed for grid-scale electricity generation, with average of wind speeds $8.9 \mathrm{~m} / \mathrm{s}$ and $9.9 \mathrm{~m} / \mathrm{s}$ at the height of $30 \mathrm{~m}$, respectively [62]. Small-scale off-grid wind turbines along the coastline and in the islands also possess great potential in Tanzania.

In Tanzania, a lot of places are being evaluated for their wind potential. The Ministry of Energy, in collaboration with Tanzania Petroleum Development Corporation, Renewable Energy Association, and Tanzania Electric Supply Company Limited (Dar es Salaam, Tanzania) is conducting wind energy resource assessments in Mkumbara (Tanga region), Karatu (Manyara region), Gomvu (Dar es Salaam region), Timbe (Mtwara region), Makambako (Iringa region), Mgagao (Kilimanjaro region), Kititimo (Singida region), and Usevya (Katavi region). Renewable Energy Association is supporting wind measurements on Mafia Island (coastal region) [63].

Currently, four companies have expressed interest in investing in wind energy in Tanzania to build wind plants with a capacity of more than $50 \mathrm{MW}$. These companies include Geo-Wind Tanzania Ltd in Dar es Salaam, Tanzania; Wind East Africa in Singida, Tanzania; and Sino Tan Renewable Energy Ltd. and Wind Energy Tanzania Ltd. in Makambako, Tanzania [64]. Wind farms with capacities of 100 MW in Singida will be constructed under the corporation of the Six Telecoms Company in Singida, Tanzania; International Finance Corporation in Washington DC, The United States of America; and Aldwych International in London, the United Kingdom. The project will cost US\$286 million [65]. Compared to other renewable energy resources that attract investment, most of the people have been trying without success to produce electricity from the wind energy. Thus, only the government and private companies are the ones who are involved in power generation assessments from wind energy resources [66].

\subsection{Solar Energy}

Globally, the total installed capacity of solar power was about 405 GW at the end of 2017, and concentrated solar thermal power capacity reached 5.1 GW with less than half (approximately 2.3 GW) in Spain, which made it the third biggest renewable power source, with photovoltaic technology the dominant source [67-69]. China, Germany, Italy, the US, and Japan possess the biggest solar photovoltaic (PV) technology capacity in the world.

In Tanzania, solar energy is used as a source of power by $24.7 \%$ of the households with access to electricity. Potential solar energy resources are found in the central parts of the country [1]. There are high solar energy levels ranging from 2800 to $3500 \mathrm{~h}$ of sunshine per year and a global horizontal radiation of $4-7 \mathrm{kWh} / \mathrm{m}^{2} /$ day $[1,70]$. According to the World Bank, Tanzania has a solar energy potential greater than that of Spain and wind energy potential greater than that of the US State of California [60]. With such great potential for solar energy resources, Tanzania is naturally appropriate for producing solar energy as a feasible alternative source for modern energy supply and rural electrification. The solar energy market in Tanzania has drastically grown and increased over the last few years. Currently, the potential solar energy resources in Tanzania are used in different parts such as solar thermal for heating and drying and photovoltaic for lighting, water pumps, refrigeration purposes, and telecommunication [1]. Solar energy is used mostly in rural areas with about $64.8 \%$ compared to urban areas with only 3.4\%. The regions of Lindi, Njombe, Mtwara, Katavi, and Ruvuma lead in the use of solar power electricity in Tanzania [18]. Despite the increasing market for solar energy applications, there are fewer signs that the government is expecting to include solar PV in the national electricity mix in any substantial way in the future [71]. However, the government insists that by 2025 , about $800 \mathrm{MW}$ will be served into the national grid from solar power generation [1].

Currently, there are more than 1,000,000 solar-powered homes in Tanzania, with solar photovoltaic panels ranging from 10 to $100 \mathrm{~kW}$ per home [72]. Different types of solar technologies exist, with diverse market and technological solutions for each one of them. They include: 
- Off-grid solar lighting or pico-solar products with 1-10 W that are small, cheap, and easy to use and provide basic lighting and phone charging services to off-grid households.

- Solar home systems with 10-200 W embrace solar panels, batteries, and inverters that can deliver a household with electricity for several devices like light bulbs, televisions, and a small refrigerator. These systems can likewise be applied to institutions like schools and hospitals.

- Mini-grids for rural electrification, which provides several large solar panels for the supply of electricity to households in rural areas.

- Big solar schemes for power generation, which can be linked to the national grid.

The government, in collaboration with other stakeholders such as private companies, is carrying out awareness and demonstration campaigns on the use of solar systems for domestic and industrial use. Value Added Tax and import tax for main solar components such as panels, batteries, inverters, and regulators have been detached to permit end consumers to get photovoltaic systems at more consistent and reasonable prices. However, there is a poor systemic mechanism to help local people boarding solar energy [73]. This enforces the need of the main energy stakeholders to sit and discuss with the local society about the best way to use these resources.

\subsection{Bio-Power}

Biopower is among the most potent types of renewable energy. Biopower can be expressed as biomass (biofuels and biodiesel), and, currently, it contributes over $83 \mathrm{GW}$ globally. Globally, roughly 2500 million people rely on wood fuels for heating and cooking. In SSA, the community use about $85 \%$ of all the wood collected from forests as fuel or charcoal for heating and cooking [74]. Although biomass from wood is renewable if the trees are replanted, it can cause negative health impacts due to indoor particulate air pollution.

In Tanzania, biomass is the largest energy source [75]. It is predominantly utilized in the domestic sector. More than 1 million people engage in charcoal production and supply. Demand for firewood and charcoal is dominated by the countryside and urban areas, respectively. For instance, Dar es Salaam city and other urban centers remain the largest charcoal consumers. A lot of biomass is from forests that are harvested traditionally and unsustainably due to factors such as weak law enforcement, low awareness, and high poverty levels [76,77]. In Tanzania, most of the biomass energy is frequently derived from forests, agricultural residue, animal dung, and solid industrial waste.

According to the UN Food and Agriculture Organization under Global Forests Resources Assessment project, Tanzania has 33 million hectares of forests and woodland but loses over 400,000 hectares of forests each year. Around $75 \%$ of wood harvested is not accounted in the government budget systems, which leads to a loss of revenue collection [78]. Households consume an average of $46.4 \mathrm{~kg}$ of charcoal per month. Residents of urban Tanzania consume an average of 93.6 to $180 \mathrm{~kg}$ of charcoal per person per year. However, the number is predicted to increase to 2.8 million hectares by 2030 because of high population growth [79]. The government loses about US\$100 million in revenue annually. Currently, about $18 \mathrm{MW}$ of grid power is generated from biomass, whereby the agro-industry is estimated to generate its own electric power of $58 \mathrm{MW}$.

Currently, there is an upsurge in modern biomass utilization. The raw materials available such as municipal solid waste, forest residue, sugar bagasse, rice husk, sisal, and coffee can used to generate power [80], as shown in Table 3. Further supplies can be acquired through sustainably harvested fuelwood from fast-growing tree plantations. 
Table 3. The quantity of modern biomass raw materials, which can be used to generate power [81].

\begin{tabular}{ccc}
\hline No. & Source & Quantity in Metric Tons Per Year \\
\hline 1. & Sugar bagasse & 1.5 million \\
2. & Municipal solid waste & 4.7 \\
3. & Forest residue & 1.1 \\
4. & Sisal & 0.2 \\
5. & Rice Husk & 0.2 \\
6. & Coffee husk & 0.1 \\
\hline
\end{tabular}

Power production from biomass is common all over the world and holds potential also for Tanzania [75,82-84]. Presently, a limited number of sugar producers and sawmills generate electricity from biomass as a central and integral part of their operations, and energy generated is utilized in their operations. At present, the Tanzanian sugar industry produces around 290,000 tonnes of sugar per year in around 40,000 hectares of dedicated land, leaving slightly less than a million tonnes of bagasse [85]. This bagasse can be utilized to generate power. Four plants use bagasse for producing electric energy and processing heat, but today only one plant produces electricity for the grid [86].

Currently, the installed capacity of sugar industries for power generation through co-generation from the bagasse is about $40 \mathrm{MW}$ [87], as shown in Table 4.

Table 4. Sugar industries, their bagasse, and their installed capacity [86].

\begin{tabular}{cccc}
\hline No. & Name of the Factory & $\begin{array}{c}\text { Available Bagasse } \\
\text { (tonnes/day) }\end{array}$ & $\begin{array}{c}\text { Installed Capacity } \\
\text { (MW) }\end{array}$ \\
\hline 1. & Kilombero & 13,729 & 10.6 \\
2. & Kagera & 3000 & 5 \\
3. & TPC & 2674 & 20 \\
4. & Mtibwa & 2511 & 4 \\
& Total & 21,914 & 39.6 \\
\hline
\end{tabular}

Furthermore, there is installed power capacity of about 21.7 MW from the sisal and wood-based industries in Tanzania, as shown in Figure 1.

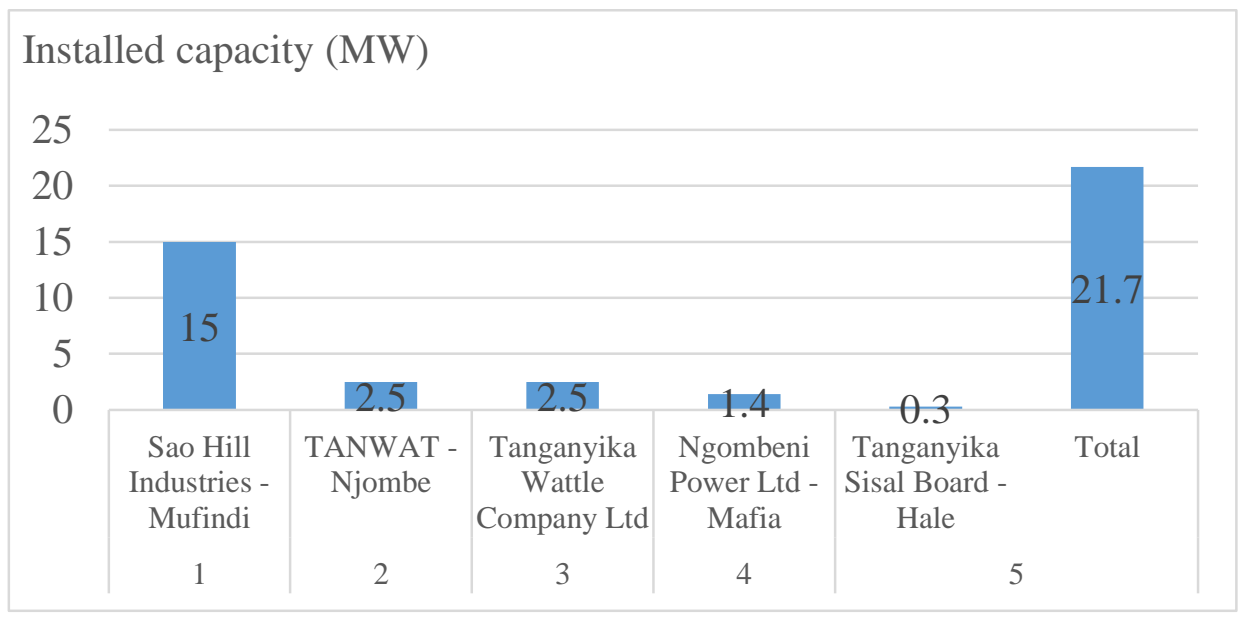

Figure 1. Installed power capacity from sisal and wood-based industries in Tanzania.

According to the Tanzania Sugar Board reports, a number of areas are considered for additional production of cane and thus are able to generate electricity. These areas include Ruipa, Ikongo, Mahurunga, and Kasulu, with a total proposed mill size of 316,000 tonnes. There are also the tentative 
sugar projects in the areas of Kisaki (Morogoro), Bagamoyo (Coast), Rufiji (Coast), Kasulu (Kigoma), Luiche/Malagarasi (Kigoma), Pangani (Tanga), and Kilosa (Morogoro). If these areas are improved for the generation of power, neighbor communities may benefit from generated power. The investment decisions of different companies should be supported to make sure that investments involving power production are optimized from a regional perspective.

Now, there are two biomass energy projects that supply power to the Tanzania Electric Supply Company Limited. These are TPC, with an installed capacity of $20 \mathrm{MW}$, and Ngombeni project, with an installed capacity of 9.6 MW in Mafia Island. Both projects are under the supervision of Standardized Power Purchase Agreement. Numerous development partners support biomass energy sector development in Tanzania. The European Union supports the preparation of the Biomass Energy Strategy, which is aimed at developing biomass energy production to increase the sustainable energy supply in the country. The Norwegian Agency for Development Cooperation (NORAD) and the Swedish International Development Cooperation Agency (SIDA) are supporting institutional and legal frameworks to develop the bioenergy (biodiesel and ethanol) subsector.

Another area with high potential in Tanzania is electricity from biogas as part of a hybrid system for community (off-grid) generation. Farms with more than a few dozen heads of cattle or similar, with manure collection, can produce biogas directly for fuel for cogeneration.

The Tanzania livestock Research Institution manages an institutional farm in Dodoma, Mpwapwa district, with more than one thousand cattle and other livestock species. There is a pronounced interest both with politicians and local researchers in investigating this potential and demonstrating the potential as a baseline for further investigations and market building.

\section{Liquid Biofuels}

Liquid biofuels can be either biodiesel or ethanol, whereby the latter is mostly produced from feedstock containing a significant amount of sugar from sugarcane or starch from maize/white. Biodiesel is produced from vegetable oil [88]. Biofuels are used to replace conventional petroleum fuels, and they are used in vehicles with less modification of the engines and fuel systems. Tanzania is blessed with a lot of potential biofuel resources, which can produce energy due to good geographic and climatic conditions for growing a broad range of biofuel crops such as Jatropha, cotton, sugar cane, palm oil, and soya bean. Most of the plant, which provides unique potential for biofuel, is Jatropha. Jatropha is currently well promoted in Tanzania, and its investments are reported to rise with strong socioeconomic and political support. In 2015, about 620,110 hectares of Jatropha were planted [89]. It is currently adapted in arid and semi-arid areas such as in Kilimanjaro and Arusha regions. However, it is also successfully grown in tropical dry areas with an average annual rainfall between 350 and $1000 \mathrm{~mm}$. The Jatropha beans/seeds are the ones used to produce the biofuels, as indicated in Figure 2 .

\subsection{Geothermal Power}

Geothermal power is ranked as the fifth biggest renewable energy source. The installed power production capacity from geothermal sources is about 13.438 GW as of 2016 [90]. One-third of the geothermal energy resources provides electricity generation, and the remaining two-thirds are used for direct heat generation. Globally, the geothermal power generation is dominated by the US, Philippines, Indonesia, New Zealand, and Italy.

Tanzania has noteworthy geothermal energy resources; however, they are not yet fully quantified. The geothermal energy resources assessments began in 1976, and, currently, Tanzania has about a total of $5000 \mathrm{MW}$ capacity, which can be produced by geothermal energy resources [65], with most prospects located in the East African Rift System [70]. In Tanzania, geothermal blessing and prospects are grouped into main three zones, namely, the northeastern zone with regions of Mara, Kilimanjaro, and Arusha; the southwestern zone with regions of Rukwa and Mbeya; and the eastern coastal belt zone in Rufiji Basin, which is related with rifting and magmatic intrusions [91]. 


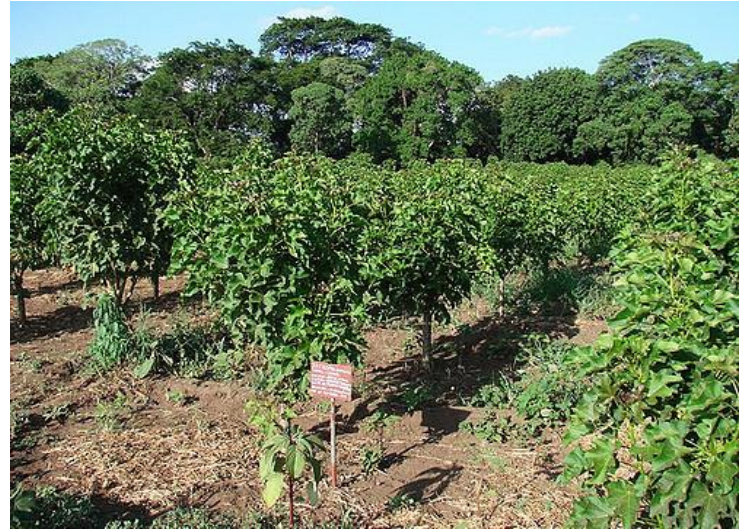

(a)

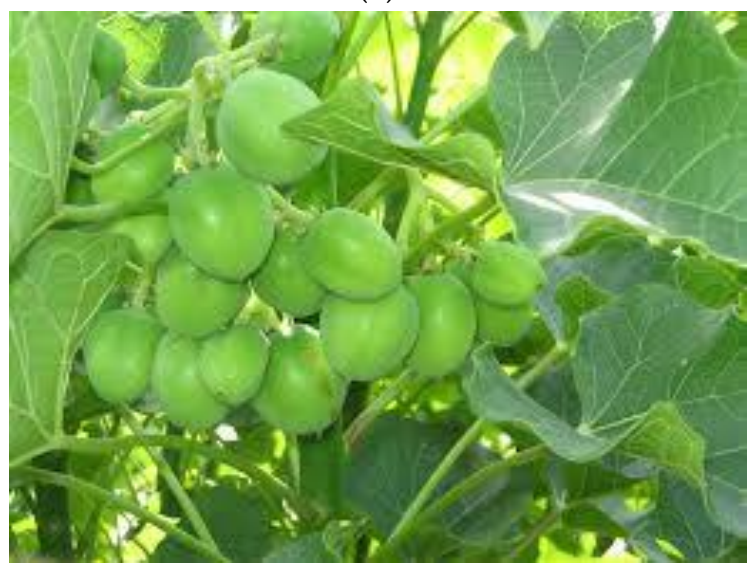

(c)

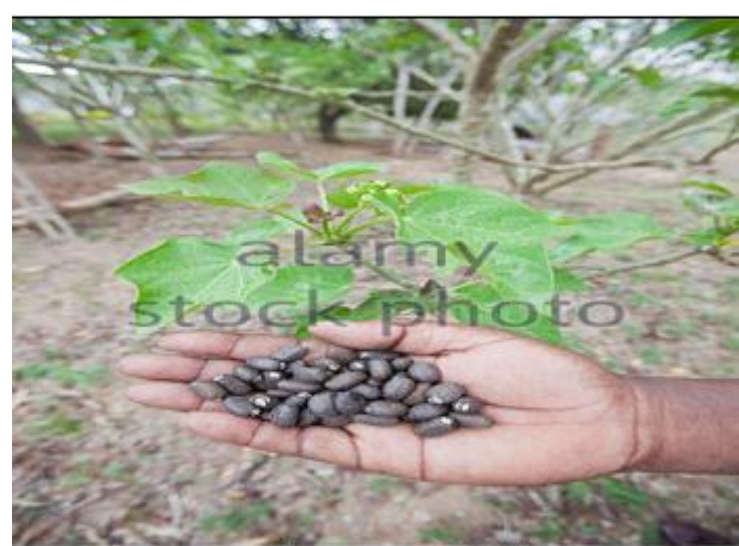

(b)

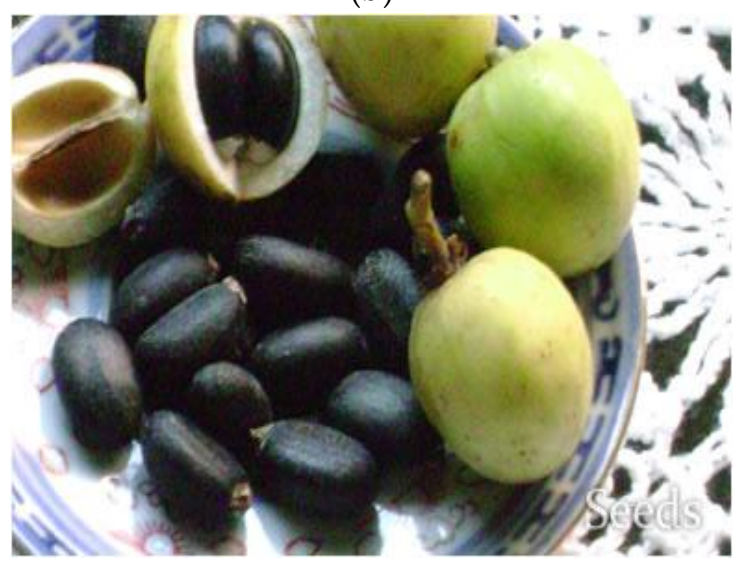

(d)

Figure 2. Jatropha plants and seeds. (a) Represents the Jatropha plantation and (b-d) represent the Jatropha beans/seeds, which are used to produce biofuels.

Among these, only the southwestern zone has undergone detailed surface exploration studies. The government under Tanzania Geothermal Development Company has completed four detailed surface studies on developing areas such as Ngozi and Kiejo-Mbaka in Mbeya region, Songwe in Songwe region, and Luhoi in Coast region. To accelerate the promotion of geothermal energy resources, the Government intends to purchase operating machines for the research, exploration, and harvesting of geothermal energy resources. This will cost Tshs 80.50 billion [65].

Ngozi geothermal steam field in southwestern Tanzania has indicated the potential of Tanzania's energy transformation. Ngozi project is financed by the Climate Investment Fund with an approved fund of US\$21.7 million [92]. This will enhance a move that will help to alleviate the high-risk nature of geothermal prospection and field development in the region.

The government formed a National Task Force on Geothermal Development to recognize the potential of geothermal resources and their contribution to energy diversification. Its main task is to advise the government on national geothermal resource development [70]. Furthermore, the government expects to prepare a Renewable Energy Policy and Geothermal Energy Act to advance and scale up Tanzania's geothermal development.

\section{Challenges of Renewable Energy Development in Tanzania}

Although Tanzania is trying to develop the renewable energy, there are challenges that disrupt the efforts that are initiated by the government and other renewable energy stakeholders in Tanzania. This study examined some of the challenges below: 


\subsection{Shortage of Human Resource and Training}

Skilled workforce to initiate, operate, and maintain renewable energy projects is a necessary tool towards successful implementation of these projects $[93,94]$. The renewable energy sector requires human resources with diverse skills in fields such as electrical, mechanical, chemical and material engineering, social work, and financial and business management [95]. Most of the renewable energy projects, especially in rural areas, require basic technical skills such as installment of essential tools for renewable energy regarding solar PV systems in rural households [96]. Currently, Tanzania has a limited number of trained personnel, training facilities, and institutions for the installation, operation, maintenance, and monitoring of renewable energy technologies and projects [97]. This impacts negatively on the achievement of sustainable, renewable energy marketing and supply. Thus, there is the need to train more people, especially in basic skills such as artisans in order to ensure that they are capable of accessing the spare parts needed to set up a new infrastructure that can offer a high-quality, enhanced, renewable resource supply to the community.

\subsection{High Initial Investment Cost}

High initial investment cost is among the critical challenges facing renewable energy development in most developing countries including Tanzania [48]. Initial investment is a unique and essential tool for any project development [98] as it enhances investor's confidence and reduces the financial gap [99]. There are few or no incentives for local manufacturing or importation of renewable energy equipment such as solar devices [71]. Although the solar power panels are duty-free except for value added tax (VAT), other solar power components like batteries and DC lamps and light bulbs still attract an import duty. This increases the cost of investment in renewable energy development in rural communities, and most of the solar power instruments that are ordered and installed are either fake or sub-standard. Most of the solar energy projects fail to function, and others work only within a short period of time after decommissioning.

\subsection{Poor Community Awareness and Information Flow}

Renewable energy technologies in developing countries including Tanzania are new [100]. A lot of people have an insufficient understanding of these technologies. Most of the issues in renewable energy development and technologies such as knowledge of its establishment, application, and socioeconomic and environmental importance are still unknown to the public. There are also fears about the economic compatibility of renewable energy development projects [101]. This is due to the fact that there is inadequate and insufficient training and awareness. Public awareness and training should be provided to remove the disparity in renewable energy development and the market that have produced an upsurge to a higher risk insight for possible prospects [102].

\subsection{Low Level of Research and Development}

Research development is crucial to enhance the exploration and establishment of new renewable energy and new technologies that can be applied to its development [103,104]. Currently, there is no visible plan being offered to academic institutions concerning renewable energy research works. There are no local or regional research centers that can provide basic research amenities and infrastructures for renewable energy technologies. Furthermore, there are poor working systems that are put forward for quality international research and development cooperation that can accelerate technological transfer [104]. This disregard slows down the development of renewable energy projects and technologies. To develop a sustainable, renewable sector R\&D is important but not sufficient. It is even more important to have enough vocationally trained energy specialists available to install and service the systems, as well as to convince and demonstrate to the local population that renewable energy sources are essential for their lives $[105,106]$. 


\subsection{Poor and Unfriendly Institutional Framework}

The institutional structure of the energy sector in most developing/less developed countries such as Tanzania is still under a central government monopoly, with the responsibility for energy generation and supply lying with local government institutions and other independent departments [48]. Also, there are institutions that formerly deal with energy production and supply in Tanzania [104]. For instance, there are The Tanzania Electric Supply Company Limited, Tanzania Petroleum Development Corporation, and Renewable Energy Association and Rural Electrification Agency, which provide inadequate coordination because of limits of institutional ability regarding the development of renewable energy technologies. This also creates an unsteady macroeconomic environment, which raises risks and diminishes investments [107]. This challenge results in the government not focusing enough on research and development and its failure to promote science while improving the humanities [108]. The government of Tanzania has to realize the decentralization of its resources and the restructuring of its energy systems to cater to the development of renewable energy development. This will further assist it to adopt future renewable energy technologies and development.

\subsection{Electricity Networks Unreliability}

Tanzania faces the problem of poor and inadequate transmission and distribution power lines in rural and remote areas where there is high demand for energy supply [109]. Unlike most renewable energy technologies, which are decentralized in nature, the present general electrical power system used in Tanzania is designed to support requirements of centralized systems [110]. This suggests that there is a need to adopt decentralized energy systems that can efficiently and effectively support renewable energy technologies.

\section{Conclusions and Recommendations}

Tanzania has great potential to develop renewable energy. However, exploration efforts have largely emphasized hydropower projects, and other renewable energy such as solar, thermal, wind, biomass, and biogas are under-utilized due to different socioeconomic and political reasons, as explained in Section 5. The government, along with other renewable energy stakeholders, should complement existing policies and strategies to address issues related to renewable energy development to ensure timely and sustainable utilization of the available resources. Also, there is the need to provide a sound business and investment environment to local and foreign people who can provide capital towards renewable energy technologies and development. There should be more training and awareness made available to the public about how to invest and use renewable energy.

Author Contributions: Obadia Kyetuza Bishoge prepared an analysis of potential renewable energy sources in Tanzania and a structure of the manuscript. Lingling Zhang prepared an analysis of sustainable development goals, and Witness Gerald Mushi prepared an analysis of the challenges of renewable energy development in Tanzania and conclusion.

Funding: This research received no external funding.

Conflicts of Interest: The authors declare no conflicts of interest.

\section{References}

1. Sarakikya, H. Renewable energy policies and practice in Tanzania: Their contribution to Tanzania economy and poverty alleviation. Int. J. Energy Power Eng. 2015, 4, 333. [CrossRef]

2. The United Nations. Goal 7: ENSURE Access to Affordable, Reliable, Sustainable and Modern Energy for All. Sustainable Development Goals. 2017. Available online: https:/ / www.un.org/sustainabledevelopment/ energy/ (accessed on 8 April 2018).

3. Owusu, P.A.; Asumadu-Sarkodie, S. A review of renewable energy sources, sustainability issues and climate change mitigation. Cogent Eng. 2016, 3, 1-15. [CrossRef] 
4. International Energy Agency. Energy Climate and Change World. Energy Outlook Special Report. 2015. Available online: https://www.iea.org/publications/freepublications/publication/ WEO2015SpecialReportonEnergyandClimateChange.pdf (accessed on 5 July 2018).

5. Souza, G.M.; Ballester, M.V.R.; de Brito Cruz, C.H.; Chum, H.; Dale, B.; Dale, V.H. The role of bioenergy in a climate-changing world. Environ. Dev. 2017, 23, 57-64. [CrossRef]

6. Energy Watch Group. Energy Watch Group New Study: 100\% Renewable Electricity Worldwide Is Feasible and More Cost-Effective than the Existing System-Energy Watch Group. 2017. Available online: http:/ / energywatchgroup.org/new-study-100-renewable-electricity-worldwide-feasible-costeffective-existing-system (accessed on 4 July 2018).

7. International Energy Agency. Global Energy Demand Grew by 2.1\% in 2017, and Carbon Emissions Rose for the First Time Since 2014. 2018. Available online: https:/ /www.iea.org/newsroom/news/2018/ march/global-energy-demand-grew-by-21-in-2017-and-carbon-emissions-rose-for-the-firs.html (accessed on 1 April 2018).

8. Ekouevi, K.; Tuntivate, V. Household Energy Access for Cooking and Heating: Lessons Learned and the Way Forward. 2017. Available online: http://siteresources.worldbank.org/EXTENERGY2/Resources/ HouseHold_Energy_Access_DP_23.pdf (accessed on 4 July 2018).

9. Apte, K.; Salvi, S. Household Air Pollution and Its Effects on Health. F1000Research, 2016. Available online: http:/ / www.ncbi.nlm.nih.gov/ pubmed/27853506 (accessed on 4 July 2018).

10. AU and EU. Science for the Building Knowledge for Sustainable Development. European Commission, 2017. Available online: http:/ / publications.jrc.ec.europa.eu/repository/bitstream/JRC107753/africa_report_ summary_en.pdf (accessed on 5 July 2018).

11. Belward, A.; Bisselink, B.; Bódis, K.; Brink, A.; Dallemand, J.-F.; Roo, A. Renewable Energies in Africa. 2011. Available online: http:/ / www.jrc.ec.europa.eu/ (accessed on 4 July 2018).

12. Climate Action. Renewable Electricity to Surpass Energy Demand in Africa by 2030_Climate Action Programme. 2017. Available online: http://www.climateactionprogramme.org/news/renewable_ electricity_to_surpass_energy_demand_in_africa_by_2030 (accessed on 8 March 2018).

13. Future Energy Africa. An African Energy Industry Report: 2018 Part of ISPY Publishing's Industry Survey, Market Intelligence, and Forecasts Series. 2018. Available online: https: / /www.futureenergyafrica.com/ media/1751/1-mir-africa-mir-18-2-es_685804715-05-2018.pdf (accessed on 4 July 2018).

14. International Energy Agency. Africa Energy Outlook. A Focus on Energy Prospects in Sub-Saharan Africa. World Energy Outlook Special Report. 2014. Available online: http:/ /www.res4africa.org/wp-content/ uploads/2016/05/WEO2014_AfricaEnergyOutlook.pdf (accessed on 4 July2018).

15. International Energy Agency. Key World Energy Statistics. 2017. Available online: https://www.iea.org/ publications/freepublications/publication/KeyWorld2017.pdf (accessed on 5 July 2018).

16. USAID. Power Africa in Tanzania: Power Africa Fact Sheet. U.S. Agency for International Development, 2018. Available online: https:/ / www.usaid.gov/powerafrica/tanzania (accessed on 12 April 2018).

17. Bonjour, S.; Adair-Rohani, H.; Wolf, J.; Bruce, N.G.; Mehta, S.; Prüss-Ustün, A. Solid fuel use for household cooking: Country and regional estimates for 1980-2010. Environ. Health Perspect. 2013, 121, 784-790. [CrossRef] [PubMed]

18. Citizen Reporter. 33pc of Tanzanians have Access to Electricity: Report-News. The Citizen, 2017. Available online: http:/ / www.thecitizen.co.tz/News/33pc-of-Tanzanians-have-access-to-electricity--report/18403403900298-9elccaz/index.html (accessed on 24 April 2018).

19. Ministry of Energy and Minerals. The Speech of the Ministry of Energy and Minerals on the Estimates of the Revenue and Expenditure for Financial Year 2017/2018; Ministry of Energy and Minerals: Dodoma, Tanzania, 2017.

20. Holden, E.; Linnerud, K.; Banister, D. Sustainable development: Our Common Future revisited. Glob. Environ. Chang. 2014, 26, 130-139. [CrossRef]

21. Barbier, E.B.; Burgess, J.C. Sustainable development: An economic perspective. In International Encyclopedia of the Social \& Behavioral Sciences; Elsevier: New York, NY, USA, 2015; pp. 823-827.

22. Guillen-Royo, M.; Guardiola, J.; Garcia-Quero, F. Sustainable development in times of economic crisis: A needs-based illustration from Granada (Spain). J. Clean. Prod. 2017, 150, 267-276. [CrossRef]

23. Georgeson, L.; Maslin, M. Putting the United Nations Sustainable Development Goals into practice: A review of implementation, monitoring, and finance. Geo. Geogr. Environ. 2018, 5, e00049. [CrossRef] 
24. Ait-Kadi, M. Water for Development and Development for Water: Realizing the Sustainable Development Goals (SDGs) Vision. Aquat. Procedia 2016, 6, 106-110. [CrossRef]

25. Pedersen, C.S. The UN Sustainable Development Goals (SDGs) are a great gift to business! Procedia CIRP 2018, 69, 21-24. [CrossRef]

26. Acheampong, M.; Ertem, F.C.; Kappler, B.; Neubauer, P. In pursuit of Sustainable Development Goal (SDG) number 7: Will biofuels be reliable? Renew. Sustain. Energy Rev. 2017, 75, 927-937. [CrossRef]

27. Barasa, M.; Bogdanov, D.; Oyewo, A.S.; Breyer, C. A cost optimal resolution for Sub-Saharan Africa powered by $100 \%$ renewables in 2030. Renew. Sustain. Energy Rev. 2018, 92, 440-457. [CrossRef]

28. Sen, S.; Ganguly, S. Opportunities, barriers and issues with renewable energy development-A discussion. Renew. Sustain. Energy Rev. 2017, 69, 1170-1181. [CrossRef]

29. IRENA. Renewable Energy and Jobs: Annual Review. 2018. Available online: http://irena.org/-/media/ Files/IRENA/Agency/Publication/2018/May/IRENA_RE_Jobs_Annual_Review_2018.pdf (accessed on 5 July 2018).

30. OECD. Overview of Progress and Policy Challenges in TANZANIA. 2013. Available online: http:/ / dx.doi. org/10.1787/9789264204348-en (accessed on 4 July 2018).

31. Afnan-Holmes, H.; Magoma, M.; John, T.; Levira, F.; Msemo, G.; Armstrong, C.E. Tanzania's Countdown to 2015: An analysis of two decades of progress and gaps for reproductive, maternal, newborn, and child health, to inform priorities for post-2015. Lancet. Glob. Health 2015, 3, e396-e409. [CrossRef]

32. The World Bank. End Extreme Poverty. Boost Shared Prosperity. Annual Report. 2015. Available online: http:/ / pubdocs.worldbank.org/en/908481507403754670/Annual-Report-2017-WBG.pdf (accessed on 4 July 2018).

33. URT. National Five Year Development Plan 2016/17-2020/21. 2016. Available online: http://www.mof.go. tz/mofdocs/msemaji/Five2016_17_2020_21.pdf (accessed on 6 July 2018).

34. Kilama, B.; George, C.; Katera, L.; Rutatina, N. Assessing Data for the Sustainable Development Goals in Tanzania. 2016. Available online: http:/ / southernvoice.org/wp-content/uploads/2016/02/Tanzania-FinalFeb-2016.pdf (accessed on 13 June 2018).

35. Helliwell, J.F.; Layard, R.; Sachs, J. World Happiness Report 2018. 2018. Available online: http: / / worldhappiness.report/ed/2018/ (accessed on 13 June 2018).

36. Todd, G.; Mamdani, M. Tanzania and the Sustainable Development Goals: Has Tanzania Prepared to Roll-Out and Domesticate the Health SDGs? 2017. Available online: http:/ /ghptt.graduateinstitute.ch/ sites/default/ files/TanzaniaSDGHealthReport.pdf (accessed on 5 July 2018).

37. Kessy, F. SDGs series \#2: Implementing SDGs in Tanzania: Prospects and challenges. Chronic Poverty Advisory Network, 4 March 2016. Available online: http:/ / www.chronicpovertynetwork.org/blog/2016/3/ 4/sdgs-series-2-implementing-sgds-in-tanzania-prospects-and-challenges (accessed on 2 July 2018).

38. Athumani, R. Tanzania: Agenda 2063 Seeks Eliminating Poverty. allAfrica.com, 31 March 2015. Available online: http:/ / allafrica.com/stories/201503311357.html (accessed on 13 June 2018).

39. Ståhl, M. Looking Back, Looking Ahead-Land, Agriculture and Society in East Africa A Festschrift for Kjell Havnevik. 2015. Available online: https://www.diva-portal.org/smash/get/diva2:850493/FULLTEXT01. pdf (accessed on 5 July 2018).

40. ESI Africa. Tanzania Sets Goal Towards Sustainable Energy [Internet]. ESI-Africa.com, 8 December 2016. Available online: https: / www.esi-africa.com/tanzania-sets-goal-towards-sustainable-energy/ (accessed on 15 June 2018).

41. The European Union in Tanzania. Empowering Tanzania. Energy for Growth and Sustainable Development. 2016. Available online: https:/ / eeas.europa.eu/sites/eeas/files/20160512_01_en.pdf (accessed on 3 July 2018).

42. The World Bank. Tanzania Renewable Energy CDM Program of Activities. 2014. Available online: http: / / projects.worldbank.org/P127585?lang=en (accessed on 15 June 2018).

43. World Future Council. 100\% Renewable Energy and Poverty Reduction in Tanzania. 2017. Available online: https: / /www.worldfuturecouncil.org/100-renewable-energy-poverty-reduction-tanzania/ (accessed on 13 June 2018).

44. Otsuki, T. Costs and benefits of large-scale deployment of wind turbines and solar PV in Mongolia for international power exports. Renew. Energy 2017, 108, 321-335. [CrossRef]

45. REN21. Renewables 2016 Global Status Report. 2016. Available online: http://www.ren21.net/wp-content/ uploads/2016/06/GSR_2016_Full_Report.pdf (accessed on 17 March 2018). 
46. Gupta, A. The world's most used renewable power sources. Power Technology, 14 January 2014. Available online: https: / /www.power-technology.com/ features / featurethe-worlds-most-used-renewable-powersources-4160168/ (accessed on 23 February 2018).

47. International Hydropower Association. Hydropower Status Report. 2017. Available online: https://www. hydropower.org/sites/default/files/publications-docs/2017HydropowerStatusReport.pdf (accessed on 15 April 2018).

48. Sergi, B.; Babcock, M.; Williams, N.J.; Thornburg, J.; Loew, A.; Ciez, R.E. Institutional influence on power sector investments: A case study of on- and off-grid energy in Kenya and Tanzania. Energy Res. Soc. Sci. 2018, 41, 59-70. Available online: http:/ /linkinghub.elsevier.com/retrieve/pii/S2214629618303566 (accessed on 27 April 2018). [CrossRef]

49. Hankins, M. Tanzaniàs Small-Hydro Energy Market. 2009. Available online: www.german-renewableenergy.com (accessed on 5 June 2018).

50. Hartung, H.; Biririza, E.M.; Jagwe, W.; Lenz, F. Advanced Scoping for Technical Capacity Building on Small Hydropower in East Africa. 2015. Available online: http://www.euei-pdf.org/sites/default/files/field_ publication_file/EAC_Advanced_Scoping_on_Techncial_Capacity_Building_for_Small_Hydropower_in_ East_Africa_Final_Report.pdf (accessed on 12 April 2018).

51. WWF. The Facts and Risks of Building Stielger's Gorge Hydropower Dam in Selous Game Reserve, Tanzania the True Cost of Power. 2017. Available online: https:/ / www.wwf.de/fileadmin/fm-wwf/PublikationenPDF/WWF-Report-Selous-True-Cost-Of-Power.pdf (accessed on 8 March 2018).

52. ESI Africa. Tanzania: Stiegler's Gorge power project to commence construction. African's Power Journal, 23 April 2018. Available online: https://www.esi-africa.com/construction-of-stieglers-gorge-powergeneration-project-to-begin-in-q2/ (accessed on 2 May 2018).

53. Ng'wanakilala, F. Tanzania invites bids for hydropower project in game reserve. Reuters. 2017. Available online: https://www.reuters.com/article/us-tanzania-power/tanzania-invites-bids-for-hydropowerproject-in-game-reserve-idUSKCN1BB1G5 (accessed on 12 January 2018).

54. Mirondo, R. Tanzania opens bids for construction of Stiegler's Gorge Project. Citizen, 30 August 2017. Available online: http:/ / www.thecitizen.co.tz/News/Tanzania-opens-bids-for-construction-of-Stieglers/1840340-4077020-4qow63/index.html (accessed on 5 July 2018).

55. IUCN. Tanzania Urged to Halt Logging Plans and Dam Project in Selous Game Reserve, as Advised by IUCN. 2018. Available online: https://www.iucn.org/news/iucn-42whc/201806/tanzania-urged-haltlogging-plans-and-dam-project-selous-game-reserve-advised-iucn (accessed on 5 July 2018).

56. JF TULAS. Controversial Dam Construction Threatens Tanzanian Game Reserve. 2018. Available online: http:/ /jftulas.blogspot.com/2018/05/controversial-dam-contruction-threatens.html (accessed on 4 July 2018).

57. Van der Zee, B. Tanzania Presses on with Hydroelectric Dam on Vast Game Reserve. Environ. Guard. 2017. Available online: https:/ / www.theguardian.com/environment/2017/jun/26/tanzania-presses-onhydroelectric-dam-vast-game-reserve (accessed on 6 July 2018).

58. Global Wind Energy Council. Global Statistics. GWEC 2017. Available online: http://gwec.net/globalfigures/graphs/ (accessed on 17 May 2018).

59. Wind Energy and Electric Vehicle Review. Top Wind Power Producing Countries. Reve 2017. Available online: https: / / www.evwind.es/2017/11/03/top-wind-power-producing-countries/61663 (accessed on 1 April 2018).

60. Tanzania Invest. Tanzania Has High Potential For Renewable Energy Projects, US Consulting Firm Indicates. TanzaniaInvest. 2015. Available online: https://www.tanzaniainvest.com/energy/tanzaniahas-high-potential-for-renewable-energy-re-projects (accessed on 15 April 2018).

61. Kasasi, A.; Kainkwa, R. Assessment of wind energy potential for electricity generation in Setchet, Hanang, Tanzania. Tanz. J. Sci. 2002, 28, 1-7.

62. Energy Charter Secretariat. Tanzanian Energy Sector under the Universal Principles of the Energy Charter. 2015. Available online: https://energycharter.org/fileadmin/DocumentsMedia/CONEXO/20150827Tanzania_Pre-Assessment_Report.pdf (accessed on 8 May 2018).

63. Herscowitz, A.; Steel, K.; Donovan, R. Investment Brief for the Electricity Sector in Tanzania Overview. 2017. Available online: https:/ / www.usaid.gov/sites/default/ files/documents /1860/Tanzania_IG_2015_05_03. pdf (accessed on 15 January 2018). 
64. ADBG. Renewable Energy in Africa: Tanzania Country Profile. African Development Bank Group, 2015. Available online: https:/ / www.afdb.org/fileadmin/uploads/afdb/Documents/Generic-Documents / Renewable_Energy_in_Africa_-_Tanzania.pdf (accessed on 8 May 2018).

65. The Minister of Energy. The Speech of the Ministry of Energy and Minerals on the Estimates of the Revenue and Expenditure for Financial Year 2018/2019. 2018. Available online: https:/ / www.nishati.go.tz/hotubaya-bajeti-ya-wizara-ya-nishati-kwa-mwaka-2018-19/ (accessed on 15 January 2018).

66. The Economist. A World Turned Upside Down—Renewable Energy. 2017. Available online: https:/ / www. economist.com/briefing/2017/02/25/a-world-turned-upside-down (accessed on 4 May 2018).

67. Simon, E. Global Solar Capacity Grew Faster than Fossil Fuels in 2017. Carbon Brief, 5 April 2018. Available online: https: / www.carbonbrief.org/global-solar-capacity-grew-faster-than-fossil-fuels-2017report (accessed on 1 July 2018).

68. Crago, C.L.; Koegler, E. Drivers of growth in commercial-scale solar PV capacity. Energy Policy 2018, 120, 481-491. [CrossRef]

69. Hansen, K.; Vad Mathiesen, B. Comprehensive assessment of the role and potential for solar thermal in future energy systems. Sol. Energy 2018, 169, 144-152. [CrossRef]

70. African Development Bank Group. Renewable Energy in Africa: Tanzania Country Profile. 2015. Available online: https:/ / www.afdb.org/fileadmin/uploads/afdb/Documents/Generic-Docu.ments/Renewable_ Energy_in_Africa_-_Tanzania.pdf (accessed on 13 May 2018).

71. Hansen, U.E.; Pedersen, M.B.; Nygaard, I. Review of Solar PV Market Development in East Africa. UNEP Risø Centre, 2014. Available online: http:/ / pubdocs.worldbank.org/en/600611475093991341/Solar-PVmarket-East-Africa-UNEP-2014.pdf (accessed on 13 April 2018).

72. USAID. Reaching for the Roofs: One Million Solar-Powered Homes in Tanzania by 2017 I U.S. Agency for International Development. 2016. Available online: https:/ /www.usaid.gov/powerafrica/newsletter/ aug2015/solar-powered-homes-tanzania (accessed on 12 January 2018).

73. Abdu, F. Tanzania: Solar Energy Offers Cost Effective Solution. Tanzania Daily News (Dar es Salaam), 2016. Available online: http:/ / allafrica.com/stories/201610170211.html (accessed on 2 April 2018).

74. Liyama, M.; Neufeldt, H.; Dobie, P.; Njenga, M.; Ndegwa, G.; Jamnadass, R. The potential of agroforestry in the provision of sustainable woodfuel in sub-Saharan Africa. Curr. Opin. Environ. Sustain. 2014, 6, 138-147.

75. Martin, M.; Mwakaje, A.G.; Eklund, M. Biofuel development initiatives in Tanzania: Development activities, scales of production and conditions for implementation and utilization. J. Clean Prod. 2009, 17, S69-S76. [CrossRef]

76. Muhumuza, M.; Balkwill, K. Factors affecting the success of conserving biodiversity in National Parks: A review of case studies from Africa. Int. J. Biodivers. 2013, 10, 1-20. [CrossRef]

77. Gain, D.; Watanabe, T. Unsustainability Risk Causality in a Private Industrial Forest: An Institutional Analysis of Factors Affecting Stand Ecosystem Services in Kochi Prefecture, Japan. Forests 2017, 8, 126. [CrossRef]

78. Smith, D. Tanzania: Illegal logging threatens tree species with extinction. Global development. Guardian 2015. Available online: https:/ / www.theguardian.com/global-development/2015/jan/14/tanzania-illegallogging-tree-species-extinction (accessed on 18 April 2018).

79. Msuya, N.; Masanja, E.; Temu, A.K. Environmental burden of charcoal production and use in Dar es Salaam, Tanzania. J. Environ. Prot. 2011, 2, 1364-1369. [CrossRef]

80. Terrapon-Pfaff, J.C.; Fischedick, M.; Monheim, H. Energy potentials and sustainability-the case of sisal residues in Tanzania. Energy Sustain. Dev. 2012, 16, 312-319. [CrossRef]

81. Kusekwa, M.A. Biomass Conversion to Energy in Tanzania: A Critique. New Dev. Renew. Energy 2013, 239-268. [CrossRef]

82. Bilgili, F.; Koçak, E.; Bulut, Ü.; Kuşkaya, S. Can biomass energy be an efficient policy tool for sustainable development? Renew. Sustain. Energy Rev. 2017, 71, 830-845. [CrossRef]

83. Amatayakul, W.; Berndes, G. Determining factor for the development of CDM biomass power projects. Energy Sustain. Dev. 2012, 16, 197-203. [CrossRef]

84. Habib-Mintz, N. Biofuel investment in Tanzania: Omissions in implementation. Energy Policy 2010, 38, 3985-3997. [CrossRef] 
85. IFAD. Bagamoyo Sugar Infrastructure and Sustainable Community Development Programme (BASIC). Final Project Design Report. 2015. Available online: https:/ /webapps.ifad.org/members/eb/115/docs/EB-2015115-R-9-Project-design-report.pdf (accessed on 12 January 2018).

86. Szogs, A.; Wilson, L. A System of Innovation? Biomass digestion technology in Tanzania. Technol. Soc. 2008, 30, 94-103. [CrossRef]

87. Bauner, D.; Sundell, M.; Senyagwa, J.; Doyle, J. Sustainable Energy Markets in Tanzania 2012. Available online: http://www.renetech.net/wp-content/uploads/2013/03/Sustainable_Energy_Markets_ in_Tanzania_I_final_.pdf (accessed on 23 April 2018).

88. Mshandete, A.M. Biofuels in Tanzania: Status, opportunities and challenges. J. Appl. Biosci. 2011, 40, 2677-2705.

89. Mkoma, S.L.; Mabiki, F.P. Jatropha as energy potential biofuel in Tanzania. Int. J. Environ. Sci. 2012, 2, 1553-1564.

90. BP. Proved Gas in BP Statistical Review of World Energy June 2017. 2017. Available online: https:/ /www.bp.com/content/dam/bp/en/corporate/pdf/energy-economics/statistical-review2017/bp-statistical-review-of-world-energy-2017-full-report.pdf (accessed on 19 April 2018).

91. ESI Africa. Tanzania Looks into Geothermal Energy. 2016. Available online: https://www.esi-africa.com/ tanzania-looks-into-geothermal-energy/ (accessed on 8 April 2018).

92. Editors. Tanzania wins funding that will de-risk geothermal exploration in Region. Renewable Energy World, 19 July 2017. Available online: https:/ / www.renewableenergyworld.com/articles/2017/07/tanzania-winsfunding-that-will-de-risk-geothermal-exploration-in-region.html (accessed on 12 January 2018).

93. Pricewaterhouse Coopers. Developing Renewable Energy Projects-A Guide to Achieving Success in the Middle East. 2016. Available online: https://www.pwc.com/m1/en/publications/documents/evershedspwc-developing-renewable-energy-projects.pdf (accessed on 12 February 2018).

94. Akadiri, P.O.; Chinyio, E.A.; Olomolaiye, P.O. Design of a sustainable building: A conceptual framework for implementing sustainability in the building sector. Buildings 2012, 2, 126-152. [CrossRef]

95. Sopian, K.; Ali, B.; Asim, N. Strategies for renewable energy applications in the organization of Islamic conference (OIC) countries. Renew. Sustain. Energy Rev. 2011, 15, 4706-4725. [CrossRef]

96. Baurzhan, S.; Jenkins, G.P. Off-grid Solar PV: Is it an Affordable or Appropriate Solution for rural Electrification in Sub-Saharan African Countries? Renew. Sustain. Energy Rev. 2016, 60, 1405-1418. [CrossRef]

97. Barry, M.-L.; Steyn, H.; Brent, A. Selection of renewable energy technologies for Africa: Eight case studies in Rwanda, Tanzania and Malawi. Renew. Energy 2011, 36, 2845-2852. [CrossRef]

98. Suárez Sánchez, A.; Krzemień, A.; Fernández, P.R.; Iglesias Rodríguez, F.J.; Lasheras, F.S.; Javier De Cos Juez, F. Investment in new tungsten mining projects. Resour. Policy 2015, 46, 177-190. [CrossRef]

99. Knuth, S. "Breakthroughs" for a green economy? Financialization and clean energy transition. Energy Res. Soc. Sci. 2018, 41, 220-229. Available online: www.elsevier.com/locate/erss (accessed on 25 April 2018). [CrossRef]

100. Gabriel, C.-A. What is challenging renewable energy entrepreneurs in developing countries? Renew. Sustain. Energy Rev. 2016, 64, 362-371. [CrossRef]

101. Union of Concerned Scientists. Barriers to Renewable Energy Technologies. 2017. Available online: https:// www.ucsusa.org/clean-energy/renewable-energy/barriers-to-renewable-energy\#.WxZrfZ8zbIU (accessed on 14 January 2018).

102. Gelil, I.A.; El-Ashry, M.; Saab, N. Arab Environment and Sustainable Energy: Prospects, Challenges, Opportunities. Arab Forum for Environment and Development, 2013. Available online: http:/ /www.idaea.csic. es/sites/default/files/Sustainable-Energy-prospects-challenges-opportunities.pdf (accessed on 5 May 2018).

103. Chen, H.H.; Lee, A.H.I. Comprehensive overview of renewable energy development in Taiwan. Renew. Sustain. Energy Rev. 2014, 37, 215-228. [CrossRef]

104. Mohammed, Y.S.; Mustafa, M.W.; Bashir, N. Status of renewable energy consumption and developmental challenges in Sub-Sahara Africa. Renew. Sustain. Energy Rev. 2013, 27, 453-463. [CrossRef]

105. Emergypedia. Technical Training for Renewable Energies and Energy Efficiency in Brazil. energypedia.inf, 2018. Available online: https://energypedia.info/wiki/Technical_Training_for_Renewable_Energies_and_ Energy_Efficiency_in_Brazil (accessed on 5 July 2018). 
106. UN Environment. Global Trends in Renewable Energy Investment 2017. 2017. Available online: http:// fs-unep-centre.org/sites/default/ files / publications/globaltrendsinrenewableenergyinvestment2017.pdf (accessed on 6 July 2018).

107. Kabir Aliyu, A.; Modu, B.; Wei Tan, C. A review of renewable energy development in Africa: A focus in South Africa, Egypt and Nigeria. Renew. Sustain. Energy Rev. 2017, 81, 2502-2518. [CrossRef]

108. Sequeira, T.N.; Santos, MS. Renewable energy and politics: A systematic review and new evidence. J. Clean. Prod. 2018, 192, 553-568. [CrossRef]

109. Ahlborg, H.; Hammar, L. Drivers and barriers to rural electrification in Tanzania and Mozambique e Grid-extension, off-grid, and renewable energy technologies. Renew. Energy 2012, 61, 117-124. [CrossRef]

110. Trotter, P.A.; McManus, M.C.; Maconachie, R. Electricity planning and implementation in sub-Saharan Africa: A systematic review. Renew. Sustain. Energy Rev. 2017, 74, 1189-1209. [CrossRef]

(C) 2018 by the authors. Licensee MDPI, Basel, Switzerland. This article is an open access article distributed under the terms and conditions of the Creative Commons Attribution (CC BY) license (http:/ / creativecommons.org/licenses/by/4.0/). 